\title{
Dimensões da liberdade indigena: missões do Paraguai, séculos XVII-XVIII ${ }^{1}$
}

\author{
Elisa Frühauf Garcia[1]
}

\begin{abstract}
Resumo
Apesar de serem considerados livres no conjunto do Império espanhol, os índios possuíam um estatuto específico, que os colocava em uma situação subordinada na hierarquia da sociedade colonial. Eles eram vinculados juridicamente às suas comunidades, criadas ou reformuladas no processo de construção do Estado na América. Tais comunidades deveriam prestar serviços ao monarca e significavam uma série de obrigações aos seus habitantes. O vínculo às comunidades e as obrigações daí advindas, muitas vezes, representavam um entrave para a realização dos seus projetos e ambições pessoais. Analisando as missões do Paraguai e as interações dos seus habitantes com a sociedade colonial na fronteira sul da América, pretendo problematizar como os índios percebiam o seu estatuto diferenciado - livre, porém com várias restrições - e demonstrar quais estratégias empregavam para atingir os seus próprios objetivos.
\end{abstract}

Palavras-chave: índios; missões do Paraguai; liberdade.

\section{Dimensiones de la libertad indígena: misiones del Paraguay en los siglos XVIII-XVIII}

\section{Resumen}

A pesar de lo facto que los indios eran considerados libres en el conjunto de lo Imperio español, ellos tenían un estatuto específico que los posicionaba en una situación subordinada en jerarquía de la sociedad colonial. Ellos fueron vinculados jurídicamente a sus comunidades, creadas o reformuladas en el proceso de construcción del Estado en América. Esas comunidades deberían proveer servicios al monarca y significaban una serie de obligaciones a sus habitantes. Lo vinculo a las comunidades y sus obligaciones, muchas veces, representaban una traba para realizar proyectos y ambiciones personales. Analizando las misiones del Paraguay y las interacciones de sus habitantes con la sociedad colonial en la frontera de Sul del América, pretendo problematizar como los indios notaban su estatuto diferenciado - libre, con diversas restricciones - y demonstrar cuales estrategias aplicaban para atingir sus propios objetivos.

Palabras-clave: indios; misiones del Paraguay; libertad.

\section{Dimensions of indigenous freedom: Missions in Paraguay, 17-18th centuries}

\section{Abstract}

Despite being considered as free individuals in the Spanish empire, the natives had a specific statute which put them in a subordinate position in the hierarchy of the colonial society. They were legally connected to their communities, created or reformulated in the process of building the State in America. Such communities were forced to provide services to the King, which meant a series of obligations on its inhabitants. The connection to the communities and the obligations resulting from it, at times, represented an obstacle for the conduct of their personal projects and ambitions. By analyzing the missions of Paraguay and the interactions of its inhabitants with the colonial society in the South border of America, I intend to analyze how the natives perceived their different statute - being free, however, with several restrictions - and to demonstrate which strategies they used to achieve their own goals. Keywords: natives; missions of Paraguay; freedom.

\section{Dimensions de la liberté des Indiens: missions du Paraguay, XVIIe-XVIIIle siècles}

\section{Résumé}

Bien que considérés comme libres dans l'empire espagnol, l'indiens avait un statut spécial qui les mettrait dans une position subalterne dans la hiérarchie de la société coloniale. Ils étaient légalement liés à ses communautés, créés ou reformulés dans la construction de l'État en Amérique. Ces communautés devraient assurer des services au monarque, donc les habitants avait des obligations. Le lien aux communautés et obligations ont souvent représenté obstacles à leur projets et ambitions personnelles. Avec l'analise des missions du Paraguay et des interactions de ses habitants avec la société coloniale dans la frontière sud de l'Amérique, on ai l'intention de discuter comme les indiens percevaient leur statut différencié - libre, toutefois avec plusieurs restrictions - et de décrire les stratégies qu'ils employaient pour atteindre leurs objectifs. Mots-clés: indiens; missions du Paraguay; liberté. 
$\mathrm{N}$ a década de 1540, um grupo de índios que vivia em Sevilha em uma situação de cativeiro irregular foi libertado seguindo as leis então vigentes. Na ocasião, os funcionários espanhóis envolvidos no caso foram surpreendidos: os índios se negaram a voltar para a América. Argumentaram que, sendo livres, poderiam escolher e, portanto, preferiam permanecer onde estavam. Dentre os motivos elencados para a escolha estava o salário: alegaram que, em Sevilha, ganhavam por uma semana de trabalho mais do que em um ano na América. Além disso, acrescentaram que se sentiam mais seguros na Europa. ${ }^{2}$

O caso, narrado por Anthony Pagden em La caida del hombre natural, suscita algumas questões pertinentes sobre o estatuto jurídico dos índios e as suas relações ambivalentes com o Império espanhol. Em artigos publicados na década de 1970, Karen Spalding já assinalava a importância de considerar a historicidade do termo "índio". Apesar de livres, não deixavam de ocupar uma posição subordinada na sociedade americana, cujo estatuto colonial derivava-se da construção de uma hierarquia entre povos conquistadores e conquistados, baseada em diferenças étnicas e culturais. ${ }^{3}$ Os índios eram classificados como "povos conquistados" que, no processo de construção da sociedade colonial, foram adjudicados a determinadas comunidades. Fundamentalmente, tratavase de uma definição jurídica que, no início dos contatos, apresentava também fortes elementos de alteridade cultural.

Com o tempo, a alteridade cultural radical existente entre os dois grupos foi se atenuando. Ambos passaram a compartilhar os códigos do mundo ibero-americano - construídos coletivamente, ainda que de maneira conflituosa e assimétrica. A manutenção da classificação estática, porém, tinha claros fins políticos: da perspectiva da Coroa e dos grupos e instituições envolvidos no estabelecimento da hierarquia colonial, ela servia como um instrumento para perpetuar as diferenças e garantir aos espanhóis o domínio da América. ${ }^{4}$

Por outro lado, até recentemente, tanto a História quanto a Antropologia empregavam uma visão um tanto essencialista na definição dos índios, bastante distante dos significados que tal classificação adquiriu historicamente, inclusive da perspectiva dos próprios nativos. Peter Gow, em trabalho sobre os piros no Peru contemporâneo, demonstra como aquela população preferia apresentar-se como mestiça e civilizada em detrimento de valorizar uma suposta pureza étnica. Segundo o autor, os piros agiam assim na expectativa de serem mais capazes de lidarem com a sociedade envolvente e diferenciaremse de seus ancestrais, cujo destino havia sido a escravidão ou outras formas de

\footnotetext{
${ }^{2}$ Anthony Pagden, La caída del hombre natural. El indio americano y los orígenes de la etnología comparativa, Madri, Alianza Editorial, 1988, p. 60.

${ }^{3}$ Karen Spalding, “¿Quiénes son los indios?", In: __.., De indio a campesino, Lima, Instituto de Estudios Peruanos, 1974, p. 147-193.

4/dem, Ibidem. Juan Carlos Estenssoro, Del Paganismo a la Santidad. La incorporación de los indios del Perú al catolicismo. 1532-1750, Lima, Instituto Francés de Estudios Andinos, 1998; Jacques Poloni-Simard, El mosaico indígena: movilidad, estratificación social y mestizaje en el corregimiento de Cuenca (Ecuador) del siglo XVI al XVIII, Quito, Abya-Yala, 2006.
} 
exploração. ${ }^{5}$ Tal como os piros no Peru do século XX ou os índios libertados em Sevilha em meados do XVI, a reação da população nativa diante da sociedade envolvente foi muito mais diversa do que a mera tentativa de manter o que seriam seus valores "tradicionais".

Neste artigo, pretendo discutir como os índios compreendiam os diferentes significados da sua condição jurídica no mundo colonial e em que medida ela foi percebida como um limite à realização dos seus desejos individuais, tendo como referência a população vinculada às reduções jesuíticas do Paraguai. Tais aspectos permitem perceber melhor os significados das ações dos índios envolvidos na experiência missionária. Os conflitos que surgiam naqueles espaços, mais do que motivados por aspectos meramente religiosos, estavam diretamente relacionados à dinâmica da sociedade envolvente.

Para grande parte da bibliografia disponível, as reduções do Paraguai seriam um exemplo bem-sucedido das políticas coloniais de isolamento dos índios. Tal sucesso teria relação direta com as demais opções então disponíveis: diante da possibilidade de prestarem serviço aos particulares, no caso, os colonos estabelecidos em Assunção e arredores, ou serem transformados em escravos pelos bandeirantes, os índios preferiam a vida nas missões junto aos inacianos. Essa perspectiva está diretamente relacionada à conjuntura de meados do século XVII, pois muitos índios se envolveram com a construção das missões em busca de alguma segurança contra a ameaça da escravidão ou da encomienda. ${ }^{7}$ No século XVIII, porém, a dinâmica social da região havia mudado consideravelmente. As cidades mais próximas das missões tinham crescido e muitos índios haviam aprendido ofícios com os quais poderiam sobreviver nos núcleos urbanos. Sua liberdade jurídica, àquela altura, já estava relativamente consolidada.

Recentemente, certos aspectos da vida no interior das reduções vêm sendo repensados por historiadores e antropólogos, em grande medida, acompanhando a ainda tímida renovação da historiografia sobre a prática missionária. ${ }^{8}$ Para o caso específico das missões do Paraguai, questionamentos sobre a homogeneidade da população aldeada, a presença de grupos não cristianiza-

\footnotetext{
${ }_{5}^{5}$ Peter Gow, Of Mixed Blood: Kinship and History in Peruvian Amazonia, Oxford, Clarendon Press, 1991.

${ }^{6}$ Para um apanhado sobre as questões teórico-metodológicas dominantes nos estudos sobre os índios e as críticas surgidas, sobretudo a partir de meados da década de 1980, veja-se: Guillaume Boccara, Mundos Nuevos en las Fronteras del Nuevo Mundo: Relectura de los Procesos Coloniales de Etnogénesis, Etnificación y Mestizaje en Tiempos de Globalización, Mundo Nuevo Nuevos Mundos, revista eletrônica, Paris. Disponível em: <www.ehess.fr/cerma.Revuedebates.htm>. Acesso em: 15 de julho de 2010; John Monteiro, "Entre o etnocídio e a etnogênese: identidades indígenas coloniais", In: __... Tupis, tapuias e historiadores: estudos de história indígena e do indigenismo, Tese apresentada ao concurso de livre docência no Departamento de Antropologia da Universidade Estadual de Campinas, Campinas, 2001, p. 53-78.

${ }^{7}$ Há uma extensa bibliografia sobre o estabelecimento das missões do Paraguai no século XVII e os conflitos envolvendo os bandeirantes. Dentre eles, veja-se: Magnus Morner, Actividades politicas y económicas de los jesuitas en el Río de la Plata, Buenos Aires, Paidós, 1968; John Monteiro, Negros da terra: índios e bandeirantes nas origens de São Paulo, São Paulo, Companhia das Letras, 1994.

¿Para uma postura crítica sobre a tônica dominante na historiografia sobre as missões, veja-se: David Sweet, "The Ibero-American Frontier Mission in Native American History", In: Erick Langer; Robert Jackson, The New Latin American Mission History, Lincoln, University of Nebraska Press, 1995; Salvador Bernabéu, "La invención del Gran Norte ignaciano: la historiografía sobre la Compañía de Jesús entre dos centenarios (1992-2006)", In: . (coord.), El Gran Norte Mexicano, Sevilla, CSIC, 2009.
} 
dos, bem como as tensões políticas e religiosas com os jesuítas têm aparecido nas pesquisas. ${ }^{9}$ No entanto, as impressões dos próprios índios sobre o regime de comunidade e as suas expectativas sobre vida no exterior dos pueblos é um aspecto ainda pouco desenvolvido pela historiografia. Em geral, os autores não consideram os contatos com os diferentes segmentos da sociedade colonial, inclusive os desenvolvidos nos núcleos urbanos, como elementos formadores da sua visão de mundo. Se a questão foi ainda pouco analisada pelos historiadores, ela não passou despercebida para os próprios jesuítas. Como veremos, os religiosos reiteradamente apontavam os contatos mantidos fora dos pueblos como a origem de condutas que eles consideravam inadequadas. Como sintetizou o padre provincial Thomas de Baeja, em 1682, os índios deixavam as missões, "entrandose en los pueblos de los españoles, y a veces entre los infieles, en cuya escuela aprenden malas costumbres". ${ }^{10}$

\section{Por indiferença, tolerância ou interesse, era relativamente fácil encontrar espanhóis na América a quem parecia que as pessoas, inclusive os indios, podiam escolher como, e com quem, queriam viver}

Os contatos com a sociedade envolvente aconteciam em diversas situações, pois os missioneiros desempenharam um papel fundamental na vida colonial do Rio da Prata. Como em outras regiões da América, eles foram solicitados para a construção das obras públicas na região e para a defesa contra as crescentes pretensões expansionistas lusitanas, especialmente as envolvendo a Colônia de Sacramento. ${ }^{11}$ Ao executarem tais atividades, os índios passavam grandes temporadas fora dos pueblos. Nessas ocasiões, estabeleciam relações com outros membros do mundo colonial e comparavam a sua condição com a dos demais súditos do monarca espanhol.

Além dessas atividades oficiais, muitos índios também deixavam as missões, individualmente ou em pequenos grupos, motivados por expectativas de uma vida melhor. Alguns permaneciam nos arredores dos seus pueblos, outros escolhiam as cidades da região. Certamente, o que lá encontravam variava de acordo com uma série de quesitos: as suas diferentes habilidades, a conjuntura, o gênero e, claro, a sorte.

\footnotetext{
9Elisa Frühauf Garcia, As diversas formas de ser indio: políticas indígenas e políticas indigenistas no extremo sul da América portuguesa, Rio de Janeiro, Arquivo Nacional, 2009; Guillermo Wilde, Religión y poder en las misiones de guaranies, Buenos Aires, SB, 2009.

${ }^{10}$ Biblioteca Nacional de España. Cartas de los PP. Generales y Provinciales de la Compañía de Jesús a los misioneros jesuitas del Paraguay, Uruguay y Paraná [Manuscritos], s.XVIII. Localización: Mss/6976. Carta del Padre Provincial Thomas de Baeja de 15 de abril de 1682, p. 118.

"Eduardo Neumann, O trabalho guarani missioneiro no Rio da Prata colonial, 1640-1750, Porto Alegre, Martins Livreiro, 1996.
} 


\section{A lei e as práticas}

As fontes apontam reiteradamente as constantes fugas dos índios e as iniciativas das diferentes autoridades coloniais para tentar solucionar tal "problema". Como já mencionado, é importante ressaltar que os missioneiros estavam vinculados ao regime de comunidade e, portanto, oficialmente a sua mobilidade dependia de autorização dos jesuítas e da administração dos pueblos, composta pelos índios chamados principais. Assim, caso estivessem fora do seu domicílio sem autorização e fossem denunciados, eles poderiam ser legalmente forçados a retornar às suas reduções de origem.

Aplicar a legislação colonial, porém, não era uma tarefa fácil: como vêm assinalando vários autores, o reconhecimento da condição jurídica de uma pessoa, ou seja, a sua qualidade, levava em conta uma série de critérios que poderiam ser manejados com relativa facilidade. Muito mais do que o fenótipo, as roupas, os sapatos, o corte de cabelo, a barba e o domínio do idioma castelhano eram elementos fundamentais para transitar de uma qualidade a outra. ${ }^{12}$ Os próprios jesuítas, apesar da considerável experiência adquirida nas atividades missionárias, às vezes, não conseguiam afirmar se os sujeitos envolvidos em determinadas situações eram índios ou espanhóis. Em certa ocasião, em 1708, quando testemunhavam sobre os assassinatos cometidos por um grupo de índios infiéis, os religiosos não souberam informar a qualidade das vítimas: segundo eles, poderiam ser espanhóis ou seus índios encomendados, pois tinham o cabelo e a barba compridos. ${ }^{13}$

Por outro lado, os princípios legais e religiosos presentes na legislação nem sempre encontravam eco na dinâmica social. Afinal, o mundo americano não era homogêneo: muitos espanhóis não compartilhavam dos projetos dos jesuítas e da Coroa, ou seja, não demonstravam uma preocupação pela manutenção do regime de comunidade e do estatuto diferenciado dos índios. Alguns nem mesmo consideravam a evangelização dos nativos necessária. Como destacou Stuart Schwartz, por indiferença, tolerância ou interesse, era relativamente fácil encontrar espanhóis na América a quem parecia que as pessoas, inclusive os índios, podiam escolher como, e com quem, queriam viver. ${ }^{14}$

Já os missioneiros que optavam por permanecer junto com os índios infiéis na chamada região da campanha, área de divisa dos Impérios ibéricos no sul da América e com pouca presença efetiva de agentes de ambos os Estados, acabavam beneficiados pelas políticas indigenistas espanholas. A Recopilación de Leyes de Indias proibia terminantemente qualquer tipo de guerra aos infiéis apenas para obrigá-los a receber a fé católica ou ainda para

\footnotetext{
12Sobre a relação entre as classificações "raciais" e a legislação colonial, o trabalho de Magnus Morner é ainda uma referência fundamental: Magnus Morner, La mezcla de razas en la historia de América Latina, Buenos Aires, Paidós, 1969. Para uma análise dos diferentes significados da mestiçagem, veja-se: Joanne Rappaport, "Quem é mestiço? - decifrando a mistura racial no Novo Reino de Granada, séculos XVI e XVII", Varia Historia, vol. 25, n. 41, jan./jun. 2009.

${ }^{13}$ Biblioteca Nacional (Rio de Janeiro) - Coleção de Angelis: doc. No 543/ I- 29, 3, 70, microfilme: MS 508 (22). Autos de las hostilidades de los indios guenoas contra los guaranís. 1708.

${ }^{14}$ Stuart Schwartz, Cada um na sua lei, São Paulo, Companhia das Letras, 2009.
} 
forçar a sua submissão aos espanhóis. ${ }^{15}$ É bem verdade que a lei não se aplicava aos índios já cristianizados: estes, caso fugissem para tais áreas, poderiam ser considerados rebeldes e punidos sem maiores empecilhos jurídicos. Porém, novamente se colocava o dilema das classificações: caso estivessem junto com os infiéis, seria difícil separar uns dos outros.

Além disso, a precariedade do governo colonial e a sua relação mutável com os índios não submetidos, ora de dependência e aliança, ora de inimizade e conflitos abertos, dificultava ainda mais qualquer tipo de ação efetiva. Buenos Aires, mesmo após tornar-se capital do recém-criado vice-reino do Rio da Prata, em 1776, era uma cidade muito próxima do território de vários grupos de índios não submetidos. ${ }^{16} \mathrm{Em}$ geral, os administradores não queriam problemas com eles: não foram poucas as vezes que os jesuítas tentaram obter ajuda para ações contra os infiéis e receberam um não como resposta. ${ }^{17}$

Assim, cientes dos empecilhos para uma efetiva punição das fugas e motivados pelas expectativas de realização dos seus objetivos, muitos índios missioneiros deixavam, temporária ou definitivamente, os seus respectivos pueblos. Alguns, como já mencionado, optavam pelas cidades da região, desde as mais próximas, Buenos Aires, Assunção, Santa Fé, até lugares distantes, como os núcleos urbanos do Peru ou os domínios portugueses.

\section{Novos horizontes}

Recentemente, a temática da presença dos índios nas cidades vem despertando a atenção dos historiadores, cujas abordagens abarcam diferentes aspectos como atividades econômicas, diferenças de gênero, aquisição de novos instrumentos culturais, entre outros. Como assinalou Felipe Castro Gutiérrez, a vigilância nas cidades, de uma forma geral, era menor e possibilitava que os índios vivessem experiências que seriam repreendidas nos seus pueblos de origem. ${ }^{18}$

Apesar da eventual menor vigilância, as cidades possuíam uma legislação específica que buscava regular as ações dos seus habitantes e restringir a presença e as atividades dos índios. Em Buenos Aires, destino de parte considerável

\footnotetext{
${ }^{15}$ Recopilación de Leyes de Indias, libro 30., título 40., leis 8 a 10. Disponível em: <http://www.congreso.gob. pe/ntley/LeyIndiaP.htm>. Acesso em: 03 de março de 2012. Sobre a discussão do estatuto dos índios no Império espanhol e os seus desdobramentos teóricos e práticos, veja-se: Lewis Hanke, Aristóteles e os índios americanos, São Paulo, Martins Editora, s/d. e Anthony Pagden, La caída del hombre natural. El indio americano y los orígenes de la etnología comparativa, Madri, Alianza Editorial, 1988. Para as políticas relativas aos índios das fronteiras, com ênfase no século XVIII, veja-se: David Weber, Bárbaros. Los españoles y sus salvajes en la era de la ilustración, Barcelona, Crítica, 2007.

${ }^{16}$ David Weber, Bárbaros. Los españoles y sus salvajes en la era de la ilustración, Barcelona, Crítica, 2007.

${ }^{17}$ Elisa Frühauf Garcia, "Entre a intolerância e a indiferença: classificações religiosas, fronteiras étnicas e políticas coloniais (Rio da Prata, século XVIII)", no prelo.

${ }^{18}$ Felipe Castro Gutiérrez, "Los indios y la ciudad. Panorama y perspectivas de investigación”, In: Los indios y las ciudades de Nueva España, México, D.F., Universidad Nacional Autónoma de México, 2010. p. 24. Sobre a temática dos índios nas cidades, há o precursor capítulo "La ciudad" de Charles Gibson, Los aztecas bajo el dominio español, 1519-1810, México, D.F., Siglo Veintiuno, 1967, p. 377-412. Dentre os trabalhos mais recentes, pode-se destacar: Jacques Poloni-Simard, El mosaico indígena: movilidad, estratificación social y mestizaje en el corregimiento de Cuenca (Ecuador) del siglo XVI al XVIII, Quito, Abya-Yala, 2006; Marta Zambrano, Trabajadores, villanos y amantes: encuentros entre indígenas y españoles en la cuidad letrada. Santa Fe de Bogotá (1550-1650), Bogotá, Instituto Colombiano de Antropología e Historia, 2008.
} 
dos missioneiros, não foram poucos os bandos expedidos pelos governadores proibindo o comércio promovido pelas índias nas ruas e buscando evitar a compra de armas e de bebidas alcóolicas por parte dos índios. ${ }^{19}$

A observância dessas restrições certamente variava: se, em geral, elas permaneciam letra-morta, em outros casos, poderiam ser severamente aplicadas, como no do índio Clemente Marín, que enfrentou problemas pelo porte de armas. ${ }^{20}$ Punidos ou não, a existência das restrições e o conhecimento do estilo de vida dos demais membros da sociedade colonial certamente suscitavam nos índios questionamentos sobre o regime de comunidade e os seus desdobramentos.

Em meados da década de 1750, por exemplo, um índio natural do pueblo de San Tomé que fugira para Buenos Aires expôs de forma esclarecedora o seu ponto de vista sobre as diferenças entre a vida dos missioneiros nas reduções e a dos espanhóis na cidade. Ele era músico e parece ter conquistado uma posição econômica e social razoável. Tocava frequentemente em bailes e, se dermos crédito às suas palavras, levava uma vida muito divertida. Resolveu então escrever uma carta aos seus conterrâneos, classificada pelo jesuíta Domingo Muriel como um "tejido de desatinos". Na missiva, escrita em meados do século XVIII, o índio chamava os missioneiros de "bárbaros e idiotas" por suportarem a vida regrada e, na sua visão, demasiado pacata das reduções. Aconselhava que todos seguissem o "exemplo" dos espanhóis: uma vida alegre, "el desordem y el vicio".

Ao que tudo indica, o tal índio de San Tomé não estava sozinho: o regime de trabalho existente nos pueblos desagradava uma parte considerável dos seus habitantes, especialmente pelos poucos benefícios materiais obtidos. Ao entrarem em contato com a sociedade colonial, muitos índios desenvolviam desejos em relação a uma série de mercadorias às quais não tinham acesso nas missões. No final da década de 1720, Ignacio de Arteaga comentava que os índios fugidos não queriam retornar aos seus pueblos. Eles alegavam que, apesar de trabalharem constantemente, não obtinham o necessário para comprar as mercadorias que desejavam. ${ }^{22}$ Segundo parece, a aspiração por produtos de origem europeia era comum entre os missioneiros. Algumas

\footnotetext{
${ }^{19}$ Real Academia de la Historia - Colección Mata Linares: Bando del Gobernador de Buenos Aires D. José de Andonaegui ordenando que salgan de la ciudad vagos, holgazanes y maleantes; que no lleven armas prohibidas; que no anden con caballos por la noche; a qué hora han de cerrar las tiendas; que ninguna india, mulata o negra vendan en la calle a partir de la oración; que ninguna persona saque de la ciudad vacas y trigo; que los extranjeros salgan de la ciudad. Buenos Aires, 6 de diciembre de 1745. Copia, 3ff. 32 cms. T.II, ff.4143; Bando de D. Diego de Salas, Gobernador Interino del Río de la Plata, prohibiendo el uso de armas vedadas; no se compren esclavos a criados, sólo a los dueños; los pulperos no vendan armas, aguardiente y vino a los indios. Buenos Aires, 14 de abril de 1763. Copia, 2ff. 32 cms. T.II, ff.154-155.

${ }^{20}$ Real Academia de la Historia - Colección Mata Linares: Disposición de D. Diego de Salas, Gobernador Interino del Río de la Plata, acerca de la ejecución del castigo del indio Clemente Marín por el uso de armas prohibidas. Buenos Aires, 15 de abril de 1763. Copia, 1f. 32 cms. T.II, f.156.

${ }_{21}^{21}$ Domingo Muriel, Historia del Paraguay, desde 1747 hasta 1767, Madrid, Suárez, 1919, p. 322-323.

${ }^{22}$ Ignacio de Arteaga a los PP. Misioneros. Yapeyú, 6 de agosto de 1727 apud Martín Morales, "Los diarios de la transmigración y de la guerra guaranítica de Tadeo Enis y Bernardo Nusdorffer (1752-1756). Invitación a la lectura", In: Karl Kohut; María Cristina Torales Pacheco (eds.), Desde los confines de los imperios ibéricos: los jesuitas de habla alemana en las misiones americanas, Frankfurt am Main, Vervuert; Madri, Iberoamericana, 2007, p. 220.
} 
décadas após o relato acima, já depois da expulsão dos jesuítas, os administradores espanhóis informavam que os pueblos estavam à beira da falência, sobretudo pelos gastos excessivos em produtos considerados supérfluos. Agora que podiam consumir sem o controle dos inacianos, os índios gastavam grande parte do que tinham, se dermos crédito às impressões de dom Carlos José de Añasco, em sapatos e leques. ${ }^{23}$

Nem todos, porém, demonstravam tanto apreço pelos bens materiais: alguns valorizavam a possibilidade de dispor como bem entendessem do seu tempo, exercendo, segundo parece, o que então chamavam de liberdade. Em 1747, o inaciano José Cardiel entrou em contato com guaranis que haviam fugido das missões e viviam junto com os charruas, classificados como infiéis. Esses guaranis não estavam isolados; ao contrário, interagiam com a sociedade colonial, especialmente quando trabalhavam sazonalmente para os proprietários de rebanhos locais. Durante o encontro, o religioso os convidou para retornarem às missões. Os guaranis responderam que não lhes agradara o modo de vida lá experimentado, onde eram obrigados a trabalhar com castigos, e se consideravam muito melhor agora, "estando libres para mudar de amo y de tierras cuando les pareciese". ${ }^{24}$

A associação entre a vida cristã e o excesso de trabalho era comum na região e revela como os conflitos não necessariamente estavam relacionados a questões propriamente religiosas. No final do século XVIII, o astrônomo português José de Saldanha perguntou aos índios minuanos por que eles não aceitavam o batismo. Saldanha argumentou que não havia muitos óbices para isso, pois eles já mantinham um contato assíduo com os portugueses e seu estilo de vida não diferia significativamente do dos demais segmentos da sociedade colonial. A resposta dos índios foi franca: "os cristãos trabalham muito para terem que comer, e vestir, e que eles [os minuanos] naquele modo de vida passam com maior descanso".25

\section{O amor e o gênero: perspectivas}

Além das expectativas de usufruir com mais liberdade do seu tempo ou de obter maiores benefícios materiais com o fruto do seu trabalho, as questões amorosas e sexuais eram também um elemento bastante conflitivo na vida dos índios. Geravam tensões no interior das missões e motivavam as fugas de homens e mulheres.

Os jesuítas estavam bastante comprometidos com as tentativas de imposição da monogamia e do sacramento do matrimônio. Sua conduta gerou conflitos

\footnotetext{
${ }^{23}$ Biblioteca Nacional (Rio de Janeiro) - Coleção de Angelis, MS-508 (26), doc.758. Informe sobre la decadencia de los pueblos de misiones, por don Carlos José de Añasco. Ciudad de las Corrientes, 26 de marzo de 1778. ${ }^{24}$ Carta y relación de las Misiones de la Provincia del Paraguay. Padre José Cardiel, S.J. Buenos Aires, diciembre 20 de 1747. apud Diego Bracco, Charruas, guenoas y guaraníes. Interacción y destrucción: indígenas en el Río de la Plata, Montevidéu, Linardi y Risso, 2004, p. 277.

25José de Saldanha, “Diário resumido e histórico" [1787], In: Anais da Biblioteca Nacional, vol. 51, Rio de Janeiro, Biblioteca Nacional, 1938, p. 236.
} 
que, eventualmente, chegaram a colocar em risco a permanência dos índios nas missões. Há um caso sugestivo ocorrido em meados da década de 1730, já analisado por alguns autores. Na ocasião, um grupo de índios abandonou algumas reduções do Paraguai e formou o seu próprio pueblo. Este era muito semelhante às missões: tinha igreja, cerimonial e até um índio que desempenhava certas funções dos párocos. À diferença das reduções, porém, no novo pueblo, a poligamia masculina era permitida. ${ }^{26}$

\section{Na missiva, o indio chamava os missioneiros de "bárbaros e idiotas" por suportarem a vida regrada e demasiado pacata das reduções}

O caso acima ilustra uma questão já bem explorada pela bibliografia: as dificuldades encontradas pelos missionários para a imposição do matrimônio católico, que contrastava com os diferentes hábitos e desejos amorosos e sexuais dos índios, genericamente designados como poligamia. A mudança advinda da inserção na sociedade colonial, porém, era mais profunda: significava a construção de novos papéis de gênero que abarcavam o conjunto da vida social. ${ }^{27}$

Nas reduções, havia um cuidado para que os matrimônios fossem celebrados o mais cedo possível e ainda mecanismos para tentar controlar as relações entre homens e mulheres. Eles deveriam ser separados desde a infância e, quando crescessem, o projeto era que os diferentes espaços físicos, sociais e econômicos fossem ocupados de acordo com o gênero. ${ }^{28}$ Em linhas gerais, muitas das expectativas dos jesuítas em relação às índias não diferiam das percepções gerais presentes no mundo ibérico sobre as mulheres. ${ }^{29}$

Um espaço significativo para a aplicação dos projetos em relação às índias era uma espécie de recolhimento, chamado de cotiguazú em guarani. Além de servir como abrigo para órfãs e viúvas, para lá também deveriam ser enviadas as mulheres que demonstrassem "algún vicio o fragilidad de su honestidad y fidelidad", especialmente durante a ausência de seus maridos,

\footnotetext{
${ }^{26}$ Guillermo Wilde, Religión y poder en las misiones de guaraníes, Buenos Aires, SB, 2009, p. 125 et seq. ${ }^{27}$ Apesar de abordar o século XIX, Laura Peers assinala algumas questões pertinentes sobre os conflitos entre as índias e os jesuítas, sobretudo quanto à sua participação na gestão política da comunidade. Laura Peers, "The Guardian of All: Jesuit Missionary and Salish Perceptions of the Virgin Mary", In: Jennifer Brown; Elizabeth Vibert (eds.), Reading beyond words: contexts for native history, Toronto, Broadview Press, 2003, p. $217-236$

${ }^{28}$ Sobre as políticas dos jesuítas em relação às índias nas missões do Paraguai, veja-se: Jean Baptista O Temporal, São Miguel das Missões, RS, Museu das Missões, 2009. p. 75 et seq.: Eliane Cristina Deckmann Fleck, "De mancebas auxiliares do demônio a devotas congregantes: mulheres e condutas em transformação (reduções jesuítico-guaranis, séc. XVII)", Revista Estudos Feministas, vol. 14, n. 3, dez. 2006, p. 617-634; María Elena Imolesi, "El sistema misional en jaque: la reclusión femenina en las reducciones jesuíticas de guaraníes", Anos 90, vol. 18, n. 34, Porto Alegre, dez. 2011, p. 139-158.

29Sobre o tema, veja-se: Isabel Morant (dir.); Margarita Ortega; Asunción Lavrin; Pilar Pérez Cantó (coods.), Historia de las mujeres en España y América Latina, Vol. II: El mundo moderno, Madri, Cátedra, 2005.
} 
na esperança de que abandonassem a sua vida "escandalosa" ${ }^{30} \mathrm{O}$ controle, porém, não era fácil: de acordo com certos testemunhos, apartar as índias dos homens era insuficiente para evitar as "tentações". Elas poderiam manter um comportamento "inadequado" entre si, segundo uma observação um tanto obscura de Montoya. ${ }^{31}$

Assim como no caso da aplicação da legislação colonial, também nas reduções havia uma considerável distância entre as normas vigentes e as práticas sociais. A documentação produzida pelos inacianos indica que a margem de manobra no espaço missionário era considerável, como se pode perceber na discussão sobre as punições infligidas às índias. Frequentemente, as tentativas de controlá-las por meio de castigos públicos não traziam os efeitos desejados. Aqueles que assistiam às punições começavam a especular sobre o motivo da pena, comentando sobre o "que ni fue público, ni aun tiene fundamento" e gerando situações constrangedoras.

Para evitar a maledicência e as suas funestas consequências, o padre Andres de Rada recomendava uma postura mais criteriosa por parte dos missionários. ${ }^{32}$ Tal recomendação foi reiterada na correspondência redigida pelos padres provinciais: os inacianos eram aconselhados a adotar uma perspectiva mais política do que estritamente moral ou teológica em relação aos "problemas" relativos à conduta das índias. Antes castigar os delitos considerados graves, deveriam sempre consultar os superiores, sugerindo que, em certos casos, poderia ser mais benéfico ignorá-los do que aplicar uma punição explícita. Possivelmente, muitos inacianos se excediam nos castigos, pois os padres provinciais também tentavam evitar algumas práticas aparentemente corriqueiras, como o corte do cabelo das mulheres. Os males daí advindos, ao que parece, eram muitos e poderiam colocar em risco certos pilares da experiência missionária, como o matrimônio: se as índias fossem "casadas, les aborrecen sus maridos y si solteras, pierden casamientos."33

A existência de regras explícitas e a percepção da questão considerando o que seriam as práticas vigentes entre os nativos antes da sua inserção nas missões por vezes obscureceram a compreensão das ações das índias: muitas fugiam ou tentavam realizar nesses espaços seus desejos sociais e sexuais. A partir dos contatos com a sociedade colonial, elas provavelmente passaram a considerar outras possibilidades, que não necessariamente convergiam com as dos índios. Ao contrário, conflitos envolvendo homens e mulheres não faltavam, sobretudo em situações de interação com outros agentes presentes naquela região. Na década de 1750, durante as tentativas de demarcação do Tratado

\footnotetext{
${ }^{30}$ Real Academia de la Historia - Colección Mata Linares. Tomo VIII, 9/1663. Capítulo del informe que D. Manuel Antonio de la Torre, Obispo de Paraguay, dio al Rey sobre una visita a las Misiones de los PP. Jesuitas, fl.131. ${ }^{31}$ Antonio Ruiz de Montoya, Catecismo de la lengua guarani, Asunción, Centro de Estudios Paraguayos "Antonio Guasch", 2011 [1640], p. 346.

${ }^{32}$ Biblioteca Nacional de España. Cartas de los PP. Generales y Provinciales de la Compañía de Jesús a los misioneros jeuitas del Paraguay, Uruguay y Paraná [Manuscritos], s.XVIII. Localización: Mss/6976. Carta del Padre Visitador y Vice Provincial Andres de Rada de 13 de abril de 1664, p. 22.

33/dem, Ibidem, Carta comum a todas las doctrinas del Padre Christoval Gomez Provincial desta Provincia su fecha desta doctrina de Santiago 4 de junio de 1675, p. 93.
} 
de Madri, os índios ficaram incomodados com a proximidade entre as índias e os soldados ibéricos. Os casados acusaram as suas esposas de "má vida" e os desdobramentos geraram embaraço a todos os envolvidos. O governador de Montevidéu, José Joaquim de Viana, que pelo visto ignorava as ponderações dos jesuítas mencionadas acima sobre o tema, mandou cortar publicamente o cabelo das índias. A atitude não agradou a ninguém: elas se sentiram humilhadas e aos maridos o castigo pareceu desproporcional. ${ }^{34}$

De acordo com os registros, os homens de origem ibérica se sentiam atraídos pelas índias e elas, muitas vezes, utilizavam as relações pessoais como um recurso para obter seus próprios fins. Em uma observação já do início do século XIX, Auguste de Saint-Hilaire afirmava que "uma multidão de homens brancos se apaixona por elas". E, se dermos crédito às suas palavras, parece que as índias não eram indiferentes a tais paixões. Ainda conforme o viajante, elas "se entregam aos homens de sua raça por dever, aos brancos por interesse e aos negros por prazer". ${ }^{35}$

\section{Viagens, conhecimentos e empoderamento político}

A opção por deixar os pueblos, porém, era complicada: nem todos encontravam o que procuravam. Por motivos diversos - decepções, saudades, necessidades - muitos voltavam e contavam aos demais as suas impressões sobre o mundo. Os instrumentos culturais adquiridos em tais andanças lhes fortaleciam, capacitando-os para compreender melhor a sociedade colonial e, eventualmente, para enfrentar politicamente os jesuítas. Uma das principais habilidades adquiridas era o domínio do idioma castelhano, principalmente porque significava uma possibilidade de acesso direto ao mundo espanhol, sem a intermediação dos inacianos.

Joanne Rappaport, ao abordar as lideranças contemporâneas dos paez na Colômbia, demonstra que muitos dos seus líderes mais importantes passaram uma parte significativa das suas vidas distantes das comunidades. Nesse período, eles adquiriram os instrumentos necessários para lidar com a sociedade envolvente. E foi justamente esse conhecimento que lhes conferiu, em suas respectivas comunidades, uma visão de poder, materializado na sua habilidade, superior à dos demais, de manejar os trâmites da burocracia estatal. ${ }^{36}$

Os missionários perceberam muito bem como o contato com a sociedade colonial modificava os índios. Já em 1678, o padre provincial Diego Altamirano alertava que, a partir do trato com os espanhóis, eles se tornavam mais "maliciosos":

\footnotetext{
${ }^{34}$ Arquivo Histórico Ultramarino, Brasil-Limites, cx.2, doc.133. Carta de Gomes Freire de Andrade a dom Pedro de Cevallos. Forte de Jesus-Maria-José, 14 de dezembro de 1757.

${ }^{35}$ Auguste de Saint-Hilaire, Viagem ao Rio Grande do Sul, 1820-1821, Brasília, Senado Federal, Conselho Editorial, 2002, respectivamente p. 347 e 431.

36Joanne Rappaport, "Introduction: Interpreting the Past", In: Cambridge University Press, 1990, p. 21-22. The Politics of Memory, Cambridge,
} 
No san menores los riesgos deste pequeño rebaño, antes cada dia se experimentan mayores, al passo que se reconoce malicia en los Indios mas crecida por ludir con los Españoles, y vivir mas a lo politico que vemos los haze inclinar a los males que no sin grave sentimiento se allan en algunos Pueblos con fundados recelos de que ha cundido mas el contagio de lo que hasta aora se ha descubierto. ${ }^{37}$

O empoderamento político obtido pelo domínio dos códigos da sociedade colonial era percebido pelos jesuítas como algo que transformava os índios em "ladinos", pessoas cuja astúcia para compreensão do mundo era superior à dos demais. A capacidade de argumentação era uma evidência dessa astúcia e deixava alguns inacianos em situação desconfortável. O padre Christobal Gomez, por exemplo, aconselhava os jesuítas a conduzirem a vida nas reduções com o máximo de "paciencia y caridad". Do contrário, poderiam ser interpelados pelos índios. Estes, já ladinos segundo Gomez, argumentavam que não poderiam ser instados a observar uma conduta de respeito pelo próximo se nem os padres o faziam. ${ }^{38}$

\section{Também nas reduções havia uma considerável distância entre as normas vigentes e as práticas sociais}

Os ladinos adquiriram um poder simbólico que lhes possibilitou enfrentar os jesuítas em momentos de crise, como ocorreu durante as tentativas de demarcação do Tratado de Madri. ${ }^{39}$ No pueblo de Yapeju, cuja localização próxima a várias cidades favorecia os contatos dos índios com a sociedade colonial, eles usufruíam de legitimidade no âmbito local e puderam contrapor-se à liderança dos inacianos. Segundo o padre Bernardo Nusdorffer, os ladinos interceptavam a correspondência dos jesuítas em busca de informações e liam as cartas em voz alta para os demais habitantes da missão. Se dermos crédito às palavras de Nusdorffer, porém, eles não liam exatamente o que estava escrito: inseriam o conteúdo que achassem necessário para convencer o conjunto dos índios sobre determinado assunto. Ou seja, eles possuíam não apenas a habilidade linguística, mas a "malícia" política de transformar o prestígio advindo de tal habilidade em um instrumento nas disputas com os jesuítas envolvendo a

\footnotetext{
${ }^{37}$ Biblioteca Nacional de España. Cartas de los PP. Generales y Provinciales de la Compañía de Jesús a los misioneros jeuitas del Paraguay, Uruguay y Paraná [Manuscritos], s.XVIII. Localización: Mss/6976. Carta del Padre Provincial Diego Francisco Altamirano de 15 de noviembre de 1678, p. 99.

${ }^{38}$ Biblioteca Nacional de España. Cartas de los PP. Generales y Provinciales de la Compañía de Jesús a los misioneros jeuitas del Paraguay, Uruguay y Paraná [Manuscritos], s.XVIII. Localización: Mss/6976. Carta para los PP Missioneros del Pa. Provl. Christobal Gomez en la Visita del anõ de 1673, p. 88.

${ }^{39}$ As tentativas de demarcação do Tratado de Madri, especialmente os conflitos envolvendo os índios, têm sido objeto de um interesse renovado pela historiografia. Sobre o tema, veja-se: Elisa Frühauf Garcia, As diversas formas de ser índio: políticas indígenas e políticas indigenistas no extremo sul da América portuguesa, Rio de Janeiro, Arquivo Nacional, 2009; Guillermo Wilde, Religión y poder en las misiones de guaranies, Buenos Aires, SB, 2009; Lía Quarleri, Rebelión y guerra en las fronteras del Plata: guaraníes, jesuitas e imperios coloniales, Buenos Aires, Fondo de Cultura Económica, 2009.
} 
aplicação do Tratado. De acordo com o inaciano, os ladinos "achavam nelas [nas cartas] o que elas não diziam e metiam a gente cem mil mentiras na cabeça". ${ }^{40}$

\section{Conclusões}

Pelas situações narradas acima, podemos perceber como a realidade do espaço missioneiro não se restringia às relações entre os índios e os jesuítas: havia muitos outros agentes envolvidos naquele contexto histórico. A interação com os demais foi um instrumento a partir do qual os índios construíram os significados de sua condição, que ora se aproximavam, ora se afastavam da legislação colonial.

Capazes de compreender o mundo, perceberam sua posição como subordinada: trabalhavam muito, mais que os outros, ganhavam pouco, não podiam desfrutar de seu tempo com "liberdade" e encontravam dificuldades para realizar seus desejos sociais, amorosos, sexuais etc. Ou seja, atribuíam à condição indígena a origem das limitações que encontravam ao longo de suas vidas. Mais do que discutir em que medida tal percepção era uma reflexo do aparato jurídico vigente, é importante apontar como ela ajuda a esclarecer as ações dos índios e os horizontes que os moviam. Muitos estavam descontentes com o regime de comunidade? Certamente. Seus desejos e objetivos, porém, estavam vinculados a experiências e expectativas surgidas a partir dos contatos com a sociedade colonial e não apenas às referências sobre o seu passado coletivo, cuja reprodução não necessariamente correspondia aos anseios de todos os missioneiros. Afinal, como assinalou Marc Bloch, citando um conhecido provérbio árabe, "os homens se parecem mais com o seu tempo do que com os seus pais".41

Assim, os índios nem sempre se definiam pelo desejo de manutenção das diferenças e da sua especificidade. Poderia ser o contrário: uma definição baseada em uma expectativa de igualdade e liberdade, percebidas, claro, em seu respectivo contexto histórico, a partir do cruzamento do paradigma de Antigo Regime e das situações concretas. É difícil, contudo, afirmar se, com as suas estratégias, os índios conseguiram o que buscavam. Sem dúvida, foram hábeis combatentes na disputa por benefícios materiais e simbólicos na sociedade colonial do Rio da Prata. Como todo mundo, porém, provavelmente acumularam êxitos e frustrações ao longo da vida.

\footnotetext{
40Bernardo Nusdorffer, "Relacion de todo lo sucedido en estas Doctrinas en orden a las mudanzas de los 7 Pueblos del Uruguai desde S. Borja hasta S. Miguel inclusive, que por el tratado Real, y linea divisoria de los limites entre las dos Coronas, o se avian de entregar a los Portugueses, o se avian de mudar a otros parajes. Setembro de 1750 a fins de 1755," In: Jaime Cortesão, Do Tratado de Madri à conquista dos Sete Povos (17501802), Rio de Janeiro, Biblioteca Nacional, 1969, p. 252. Para uma análise do papel da escrita durante a Guerra Guaranítica, veja-se: Eduardo Neumann, Práticas letradas Guarani: produção e usos da escrita indígena (séculos XVII e XVIII), Tese de Doutorado em História, Universidade Federal do Rio de Janeiro, Rio de Janeiro, 2005.

${ }^{41}$ Marc Bloch, Introducción a la historia, México, D.F., Fondo de Cultura Económica, 2000, p. 39.
} 